\section{Questión}

Periodismo / Comunicación ISSN 1669-6581

"La radio tiene la fuerza y la potencia de la construcción de las ideas"

Cinthya García.

Question/Cuestión, Vol. 2, N 66, Agosto 2020

ISSN 1669-6581

https://perio.unlp.edu.ar/ojs/index.php/question/index

IICom-FPyCS-UNLP

\title{
“LA RADIO TIENE LA FUERZA Y LA POTENCIA DE LA CREACIÓN DE LAS IDEAS"
}

\section{"THE RADIO HAS THE STRENGTH AND POWER OF THE CREATION OF IDEAS"}

\section{Cynthia García}

Dirige \#LaGarcía, plataforma digital de comunicación popular. Premio Rodolfo Walsh 2017. Co conductora con Víctor Hugo Morales en AM 750 el programa La Mañana.

Twitter: Cynthia García @cyngarciaradio

\section{Resumen}

Cynthia García repasa su situación con la radio, la caracteriza y piensa a la mujer en el ejercicio del periodismo radiofónico. 


\title{
Palabras clave
}

Radio, Periodismo, Mujeres, Comunicación popular

\begin{abstract}
Cynthia García reviews her situation with the radio, characterizes it and thinks of women in the exercise of radio journalism.
\end{abstract}

\section{Keywords}

Radio - Journalism - Women - Popular communication

\section{Enlace}

https://go.ivoox.com/rf/55580203 